\title{
Ethical Deterioration in The Modern World
}

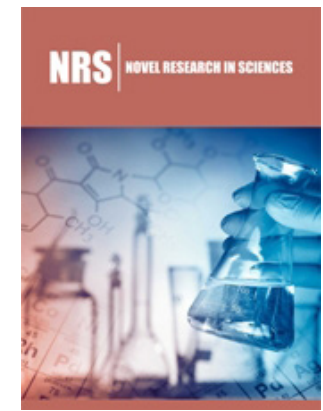

*Corresponding author: James F Welles, PhD, P.O. Box 17, East Marion, New York, USA

Submission: 毕 October 1, 2019

Published: 眥 October 22, 2019

Volume 2 - Issue 3

How to cite this article: James F Welles. Ethical Deterioration in The Modern World.Nov Res Sci.2(3). NRS.000536.2019. DOI: 10.31031/NRS.2019.2.000536

Copyright@ James F Welles, This article is distributed under the terms of the Creative Commons Attribution 4.0 International License, which permits unrestricted use and redistribution provided that the original author and source are credited.
James F Welles*

East Marion, New York, USA

\section{Opinion}

Ethics have always been the weak sister of control systems. They are holdovers from tribal values which had to be internalized to be truly effective. In addition, self-interest is invariably working counter to ethical conduct as the individual acknowledges membership to the group over-rides his/her immediate, short-term, selfish best interest-e.g., sharing food.

In the mid-19 ${ }^{\text {th }}$ century, the small town characterized life in Western civilization. Everyone knew everyone else to the degree that the birth of a new member or loss of an older one was common knowledge to all. In addition, everyone knew who was honest or shady. If there were two butchers in town and one jimmied his scale, customers went to his upright competitor, so playing by the rules was in everyone's best interest.

By the middle of the $20^{\text {th }}$ century, the city had come to define Western life, and individuals became lost in the shuffle. Personal interactions became public relations games designed to foster a positive image over a valid reality. If someone short-changed a fellow member of society, so much the better for the clever-at-heart. No one else much was likely to know about the event, and there was always another boob coming along to con out of whatever could be gained by a shrew dealer. In the 1950's some people still internalized old-tyme ethics because their elders taught them to do so, but the sharpies were on the rise abetted by mass media advertising and faceless crowds.

Now, with the internet, anonymity has taken over to the degree that anything goes, and no one can be held accountable for whatever is posted for public consumption. Emphasis is entirely on speed at the clear expense of validity, so it hardly pays to be honest in a cyberworld of frauds. Any-one who subscribes to professed group values is taken to be a fool. It is easy to predict that ethics will play a reduced role in the devolving $2^{\text {st }}$ century. From scientists devoted to publishing mis-information to law enforcers committing crimes themselves, it will be increasingly difficult to find anyone who will do what he/she should simply because it should be done.

Let's say "Should" is on the way out. 